\title{
Impact of Job Autonomy on Organizational Commitment and Job Satisfaction: The Moderating Role of Organizational Culture in Fast Food Sector of Pakistan
}

\author{
S. M. M. Raza Naqvi ${ }^{1}$, Maria Ishtiaq ${ }^{1}$, Nousheen $\mathrm{Kanwal}^{1}$ \& Mohsin $\mathrm{Ali}^{2}$ \\ ${ }^{1}$ Department of Management and Social Sciences, Muhammad Ali Jinnah University, Pakistan \\ ${ }^{2}$ University Institute of Management Sciences, Arid Agriculture University, Pakistan \\ Corresponding: S. M. M. RazaNaqvi, Faculty of Management Sciences, D-Block, First Floor, Office \#102, \\ Mohammad Ali Jinnah University, Islamabad Express Highway, Near Kaakpul, kahuta Road Sihala, Zone-V, \\ Islamabad, Pakistan. E-mail: razanaqvi@jinnah.edu.pk
}

Received: May 23, 2013

doi:10.5539/ijbm.v8n17p92
Accepted: June 19, $2013 \quad$ Online Published: August 10, 2013

URL: http://dx.doi.org/10.5539/ijbm.v8n17p92

\begin{abstract}
This study inspected the effect of job autonomy on job satisfaction and organizational commitment with a moderating role of organizational culture in the fast food sector of Pakistan. A sample of 107 employees was considered for this study. Employees included waiters, managers, supervisors and floor incharges of top fast food restaurants operating in Rawalpindi and Islamabad. Results showed that an increase in job autonomy results in an increased level of job satisfaction and organizational commitment and organizational culture moderates this relationship.
\end{abstract}

Keywords: job autonomy, organizational commitment, job satisfaction, organizational culture, fast food sector

\section{Introduction}

Job autonomy is considered as a chief characteristic of work and possibly the most extensively studied job characteristic. Numerous studies have been conducted to examine how work autonomy is associated with certain work outcomes. Research on job autonomy has gained the attention of researchers because of the benefits it brings not only to the individuals but also to the organizations. Job autonomy improves performance because when employees are provided a support to exercise job autonomy then they will consider that they are trusted to perform the task. This perception leads to an increased level of intrinsic motivation and the outcome is effectiveness in work.

Every organization that wants to be successful and to retain its employees must make sure that its employees are satisfied. An organization with a greater number of satisfied employees has the tendency to be more effective and satisfied workers are found to be more productive as compared to the workers who are not satisfied. The purpose of conducting this study was to discover and understand the impact of job autonomy on job satisfaction and organizational commitment in the fast food industry of Pakistan.

The commencement of the food service industry is credited to restaurants that started in France during the eighteenth century. Due to the changes and revolutions over time, it put up the concept of fast food in the food service industry.According to Malaysian Palm Oil Fortune (2011), the fast food industry beganin Pakistan formally with the entry of chains like McDonald's, Pizza Hut and also KFC during 1997 and 1998. The fast food industry nurtured at a speedy rate of nearly $20 \%$ per year till 2007 but this growth rate reduced to $10 \%$ per annum during 2008 to 2010. The fast food chains operating their business in Pakistan have together more than 200 outlets providing their services to more than twenty thousand people at a time. The fast food sector has molded itself as an organized segment and a huge number of overseas and local chains have established their setups in large cities of Pakistan like Karachi, Lahore and Islamabad. Pizza Hut is leading among the foreign and domestic fast food chains operating in the country with $32 \%$ share. The share of KFC is around $25 \%$ and McDonald's is estimated around $16 \%$. Subway is on the fourth rank with a $7 \%$ market share whereas the collective contribution by other fast food players is $20 \%$. Work in the fast food industry is so monotonous that employee decision making and freedom of choice have been relegated to the background. In most cases, their work is degraded, estranged and not good enough for the human spirit. Workers consider that their work is a dead-end job which has reduced their 
opportunities in life. It is also presumed that there are long working hours, less pay, the monotonous nature of the job and low job security that cause job dissatisfaction.

There is growing evidence to suggest that although employees are working harder and they take their work much seriously but still they seem to be less passionate and less satisfied and less committed to their organization because they are restricted from working freely and making decisions regarding their own work by themselves. Organizational culture is taken as a moderator as leaders are the ones who shape principles and values of an organization and organizational culture controls the way employees make a decision, it guides them about the organizational policiesas well as it also represents how much autonomy will be given to employees.

\subsection{Research Questions}

1) What is the interrelationship between job autonomy, job satisfaction as well as organizational commitment?

2) Does organizational culture moderate the connection between job autonomy, job satisfaction and organizational commitment?

\subsection{Research Objectives}

$>$ To find out how much autonomy is given to employees in the fast food industry of Pakistan.

$>$ To find out the job satisfaction level of employees.

$>$ To find out what type of organizational culture prevails in the fast food industry of Pakistan.

\subsection{Significance}

If we talk about Pakistan then much research is conducted on other sectors except fast food to check the job satisfaction level of employees and also their level of commitment to their organizations. Only limited research has been done on fast food sector employees so, the focus of this study was to determine the impact of job autonomy on job satisfaction and organizational commitment in the fast food sector of Pakistan with the moderating role of organizational culture.

\section{Literature Review}

\subsection{Job Autonomy}

The theory of work design by Hackman and Oldham is used by many organizations considering it asa foundation for management practices which lead to enhanced motivation, better work performance, and improved satisfaction of employees, decreased level of absenteeism as well as higher commitment. Autonomy is taken as one of numerous essential job design characteristics which have been used by a large number of researchers (Smith, Kot \& Leat, 2003).

Job autonomy is defined as the degree to which the job offers considerable liberty, proving free hand and choice to the individual in scheduling the work and also defining themeans to achieve the tasks (Hackman \& Oldham 1975; Marchese \& Ryan, 2001; Morgeson, Delaney-Klinger \&Hemingway, 2005; Parker, Axtell \& Turner, 2001). More specifically it can also be defined as the choice and freedom inborn in the job to perform numerous tasks (Brey, 1999).

Autonomy and control are sometimes confused so it is important to distinguish them. Control includes shaping projects and tasks, means of work and also working circumstances whereas Autonomy includes to making free choices from continuous observation and also from interaction with the supervisor (Schwalbe, 1985).In other words autonomy refers to sanctioning one's actions at a higher level (Dworkin, 1988; Gagne \& Deci, 2005).

Professionals can be successful if they are talentedand they have ability to compete in their profession, they must use a body of knowledge which supports their work and they must possess autonomy to make decisions in their work (Ozturk, 2011). Autonomy involves responsibility for the outcomes of the work which results in outcomes like high work efficiency and higher levels of intrinsic motivation (Hackman \& Oldham1976; Langfred \& Moye, 2004). Chung (1977) emphasized that autonomy has an impact on work methods, work pace and goal setting. Individuals with autonomy have the liberty to control the pace of work and to regulate work processes and evaluation procedures. Autonomy and independence are not the same as autonomous workers may depend on interpersonal communication in order to complete the interdependent tasks (Dee, Henkin\& Chen, 2000).

Job autonomy results in an improved job performance because individuals think and consider themselves skillful and creative in accomplishing their tasks (Saragih, 2011).Individuals who experience high job autonomy are less constrained by the situational factors than the individuals who experience low autonomy (Gellatly \& 
Irving, 2001). Work-role transitions theory (Nicholson, 1984) suggested that autonomous workers are able to determine the means and ends of work, as well as the timing of processes (Black, 1988). From this literature following hypothesis can be formulated:

H1: Job autonomy is significantly allied to job satisfaction and organizational commitment.

\subsection{Organizational Commitment}

Organizational commitment forms the basis of a wide-ranging literature which has focused both on the background of organizational commitment and its consequences on work behavior e.g. turnover, job performance etc. Research conducted on organizational commitment has given more attention to the psychological attachment of personnel to their workplaces, possible factors contributing to this attachment and the consequences of the attachment (Cole \& Bruch, 2006) whereas in past organizational commitment was only limited to the individual's attachment (behavioral commitment) to the organization (Iqbal, 2010) but now literature has moved towards its large number of facets that effect organizational outcome.

A study carried out by Jaros in 1997 indicated that loads of studies focusing on organizational commitment have been published in major organizational behavior journals in the recent years (Leow \& Khong, 2009). Researchers are interested in organizational commitment as it is a vital part of the employee's psychosocial state because employees with agreater level of organizational commitment are mostly engaged in behaviors like high performance in job and citizenship activities, which are supposed to be beneficial for the organization (Podsakoff, MacKenzie, Paine \& Bachrach, 2000). Different studies on organizational commitment revealed that it is based on work experience rather than the selection of employees (Addea, Parboteeah \& Velinor, 2008).

Researchers have studied the concept of organizational commitment in a variety of ways. The majority of research related to organizational commitment can be viewed in terms of attitudinal versus behavioral conceptualizations (Jamaludin, 2011). Organizational commitment can be defined as the individual's identification and his level of engagement with his organization. It reflects an individual's attitude towards the goals, objectives and values of the organization as well as his wish to stay with the organization and it also shows the level of efforts done by the individual. The latter is concerned with behavioral implications, but the concept focuses more on how individuals take their relationship with their organization and then the attitude of individuals is based on that relationship (Alhaji\&Yusoff, 2012).

Organizational commitment can also be defined as an attitude which involves loyalty of employees to the organization and it involves the internalization of goals and objectives and the willingness of employees to play a role in achieving those goals and objectives (Atak, 2011; Altindis, 2011). Porter and his associates in 1974 studied the concept of organizational commitment as the strength of an individual's identification and his sincerity with his organization (Angle \& Perry, 1981; Yousef, 2003). Therefore it is the attachment of an individual and sense of loyalty to his organization (Galunic \& Anderson, 2000; Hunt \& Morgan, 1994).

Generally three elements of commitment are mostly studied which are affective, normative and continuance (Stevens, Beyer \& Trice, 1978; Gonzalez \& Guillen, 2008; Kassahun, 2005). All these elements are independent in nature. They are exposed by individuals at different levels oforganization and all of the mentioned types of commitment are not significantly allied to the organizational performance (Meyer \& Allen, 1997) like an employee with low affective as well as normative commitment however with high level of continuance commitment does not perform very well. The reason why such employee is associated with an organization is because he has no good job opportunity.

Literature on organizational commitment is based on two majorlines: the exchange approach and the investment approach. According to social exchange approach responsibilities resultfrom the interactions and exchangesbetween parties who are in a state of joint interdependence (Saks, 2006; Sinclair, Leo \& Wright, 2005). This approach states that the organizational commitment of an individual is dependent on individual's perceived balance of reward benefits over input utilities .In other words it focuses on the exchange relation between an individual and an organization. The more favorable the exchange is from the individual's point of view the greater is his level of commitment to the organization (Johnson, Korsgaard \& Sapienza, 2002; Mohamed, Taylor \& Hassan, 2006).

The investment approach focuses on the time element. The longer the duration of employment of an individual in an organization, the more that individual wants to stay. This is mainly dependent on various acknowledgements such as tenure and pension benefits (Abdulla \& Shaw, 1999).

When more responsibilities are given to employees, they are assigned tasks with great rewards, they are provided with decision making power and are given a platform to share their ideas then they feel more 
empowered and will be more committed to the organization (Sarboland, 2012). Employees who are loyal, devoted and sincere to the organizations in which they are working are less engaged in thinking of leaving and are willing to accept change (Lo, Ramayah \& Min, 2009). From this the following hypothesis can be formulated:

$\mathrm{H} 2$ : Organizational commitment is significantly allied to job autonomy.

\subsection{Job Satisfaction}

Job satisfaction has become a highly important subject in social sciences. It has been debated in the literature that answers to questions about how people feel about their job are not worthless but instead they convey important information on the individual's behavior such as job quit (Shields \& Price, 2002), productivity and absenteeism (Kehinde, 2011). Moreover, job satisfaction also plays a vital role in predicting the well-being of an employee (Judge \& Watanabe, 1993).

Any organization that wants to be successful and to retain the employees must make sure that its employees are satisfied (Berry, 1997). An organization with greater number of satisfied employees has the tendency to be more effective (Robbins \& Judge, 2007) and satisfied workers are found to be more productive as compared to the workers who are not satisfied.

Job satisfaction, its causes, reasons, its elements and features have been defined by many researchers across many perspectives. Some of the most commonly used definitions of job satisfaction include Porter, Bacon, Robbins and Higman (1975) who defined job satisfaction as one's reaction against his/her profession or organization. Ellickson and Logsdon (2002), defined job satisfaction as the degree to which employees are attracted towards their work. Weiss (2002), demarcated job satisfaction as a positive or pleasurable emotive and expressive state which is a result of the evaluation of one'sownjob or job experiences. According to Lease (1998), job satisfaction is actually the affective commitment of an individual towards his role in the organization and Oshagbemi (2003) defined job satisfaction results from comparing desiredoutcomes with actual outcomes.

Job Characteristics Model (Hackman \& Oldham, 1976) stated that the jobs which are created by keeping in mind the factor of intrinsic motivation lead to increased job satisfaction. An intrinsically motivating job contains five job characteristic like task identity, task significance, skill variety, autonomy and feedback. According to this theory the task itself is a way to motivate employees and the jobs which contain these five core job characteristics are found to be more motivating and satisfying as compared to the jobs that don't contain these characteristics.Similarly Rose (2001) studied job satisfaction across two main dimensions i.e. intrinsic and extrinsic sources. Intrinsic sources depend on characteristics of the person himself such as his initiative taking nature, dealings and his association with his supervisors and his own performance. Extrinsic sources include financial and materialistic rewards such as bonus, higher rank or position or job security. According to him in order to be satisfied both the facets i.e. intrinsic and extrinsic are equally important.

Majority of the employees seek autonomy in order to perform effectively. Few researchers have found anencouragingbond between autonomy and job satisfaction. Individuals feel proud of their jobs if they are given autonomy (Mehmood, Irum, Ahmed \& Sultana, 2012). From this the following hypothesis can be formulated:

H3: Job satisfaction is significantly allied to job autonomy.

\subsection{Organizational Culture}

Traditionally, culture as a scientific subject was studied by the anthropologists (van Muijen et al., 1999). For over a century the concept of culture has been central to anthropology and folklore studies. Practitioners from these disciplines have produced a massive body of literature and during the 1940s and 1950s some of their research was about the customs and traditions of the work organizations (Hatch, 1993). The concept of organizational culture was first introduced in the 1970s and 1980s (McSweeney, 2002). Organizational research initially focused on the corporate climate, but in the 1980 s organizational climate was swapped by a notion of organizational culture to some extent. Some theorists have confused both the terms. These two constructs have close similarities but there are also distinct differences. One major difference is thatclimate focuses on the perceptions of individuals about an idea or a thing, whereas culture includesvalues, and patterns of behavior (Leidner\&Kayworth, 2006).

The word culture describes the effects of people's behaviors not only on the level of their organizations but also on the level of society. Culture is viewed as a means of thinking, feeling, and also reacting that helps in differentiatingmembers of one group from other groups (Tosi \& Greckhamer, 2004; Willcoxson \& Millett, 2000). Everyone knows that every corporation has a unique culture (Chang, 2011; Hofstede, 2002) and it improves over time to reflect the identity of an organization across two dimensions: visible and invisible. Mission, philosophy 
and values are reflected in the visible dimension of culture and the invisible dimension includes a set of values that guide employees in case of their actions and perceptions (Al-Alawi, Al-Marzooqi \& Mohammed, 2007).

Organizations are structures and arrangements created by individuals and organizational culture is a result of the activities of those individuals. It is socially constructed. Individuals then create, manage and change the culture according to their way of thinking and needs (Pettigrew, 1979). Organizational culture is a product of people who may at first share some beliefs and then who build and encourage a more fully developed ethos that defines that group's relationship and purpose. The social nature of organizational culture indicates that each culture is unique; although there will be commonalities among organizations but no two organizations will be exactly identical (Budd, 1996). According to researchers like Trice and Beyer culture is a result of ideologies. These ideologies are sometimes not understood by the members of an organization and they are even not shared by all members but they are still encouraged to engage in some behaviors while staying away from others (Haas \& Hwang, 2007).

According to a theorist Schein, organizational culture is set of expectations and assumptions which a group learns as it engages itself in solving its problems. So organizational culture is an outcome of group experiences (Ogbonna \& Harris, 2000; Lim, 1995).

Researchers give credit to the culture of an organization for being successful. Theorists have found that successful companies had cultures that were passed on through story or its legends and thus motivated their employees. Organizational culture is one of the fundamental determinants of progress in management. It forms the base of a firm's identity and it shows the manner in which the companies operate in the market (Jakonis, 2009). Culture is also important because it helps to balance organizational structure by filling in the gaps that exist in formal organizational structures (James, 2000). Some scholars have viewed organizational culture as a property of the group or an organization itself, like structure or technology. Others have viewed it as something that resides within each individual as a function of cognitive and learning processes (Deshpande \& Webster, 1989).

Organizational culture can affect the way people set goals both personal and professional and also how they perform their jobs. In other words organizational cultures affects the way in which people think, feel, perceive and act (Lok \& Crawford, 2003). Due to this reason organizational culture is often mentioned as the main reason of the failure of an organizationand this failure occurs because it doesn't change its culture with change in needs and time (Linnenluecke \& Griffiths, 2010).

Organizational culture has a great impact on employees both in direct and indirect way. Researchers suggest that organizational culture influences the productivity of an organization, effectiveness, its performance, job satisfaction, commitment, innovativeness and leadership and decision-making (Mehr, Emadi, Cheraghian, Roshani \& Behzadi, 2012). From this discussion following hypothesis can be formulated:

H4: Organizational culture plays a moderating role between the relationship of job satisfaction and organizational culture.

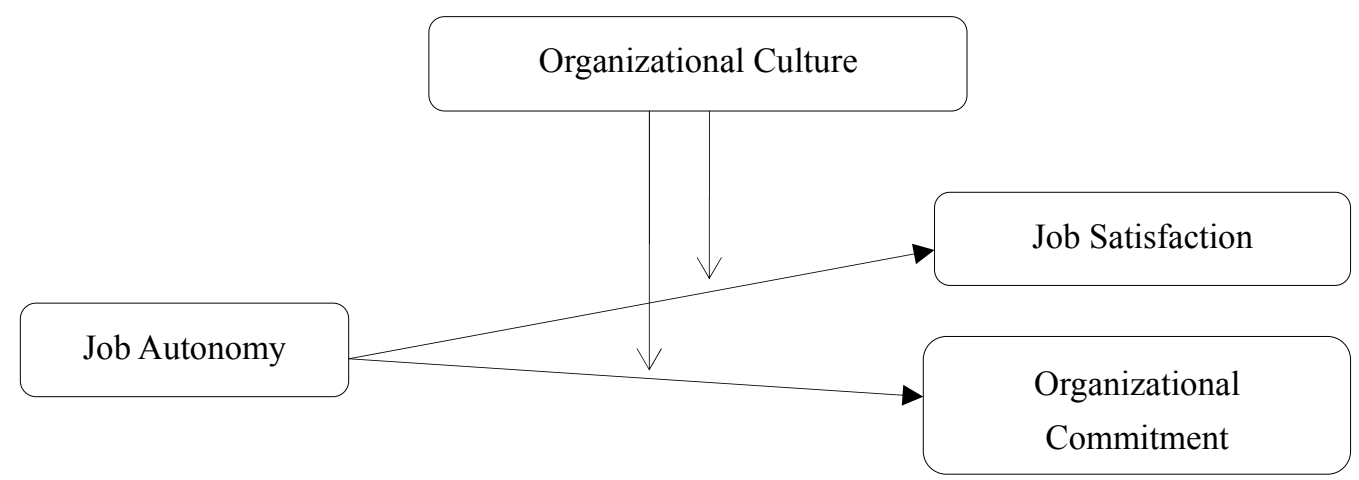

Figure 1.Conceptual frame work

\section{Methology}

\subsection{Research Design}

This study was conducted with an intention to study the impact of job autonomy on job satisfaction and organizational commitment with the moderating role of organizational culture in the fast food sector of Pakistan. 


\subsection{Quantitative Research}

This study was quantitative as data were collected with the help of questionnaires from respondents and then data were analyzed with the help of SPSS.

\subsection{Cross Sectional Study}

This study was cross sectional in nature as data were collected only once from respondents and was then analyzed with the help of SPSS.

\subsection{Unit of Analysis}

For this study unit of analysis was an individual.

\subsection{Population}

The subject of this study was waiters, managers, supervisors and floor incharges working in fast food restaurants of twin city i.e. Rawalpindi and Islamabad. Famous fast food restaurants operating in twin city are Pizza hut, McDonalds, KFC, Subway, Hardees, SavourCrispo, Domino's Pizza and Pappasallis. In this study all of the mentioned restaurants were targeted. 200questionnaires were distributed but only 107 were returned back and this made the response rate as $53.5 \%$.

Table 1.Sample characteristics

\begin{tabular}{clcc}
\hline Description & & Frequency & Percentage \\
\hline Gender & Male & 98 & 91.6 \\
& Female & 9 & 8.4 \\
Qualification & Intermediate or less & 52 & 48.6 \\
& Bachelors & 40 & 37.4 \\
& Maters & 14 & 13.1 \\
& MS & 1 & 0.9 \\
Age & $20-30$ & 40 & 37.4 \\
& $31-40$ & 50 & 46.7 \\
& $41-50$ & 17 & 15.9 \\
& Waiter & 76 & 71.0 \\
& Manager & 15 & 14.0 \\
& Supervisor & 10 & 9.3 \\
& Floor incharge & 6 & 5.6 \\
\hline
\end{tabular}

\subsection{Procedure}

Data were collected with the help of personally administered questionnaires in order to save time. Out of 200 questionnaires 57 were left with the waiters, managers, supervisors and floor inchargesas they were busy and they resisted filling the questionnaires due to time constraint. All of them were assured about the confidentiality of research.

\subsection{Sampling Technique}

For this study convenient sampling technique was used and questionnaires were given only to those waiters, managers, supervisors and floor incharges who were conveniently available.

\subsection{Instrument}

\subsubsection{Demographics}

Demographics section included age, gender, education and job title.

\subsubsection{Job Autonomy}

For the measurement of job autonomy three items were adopted from Bashir, S.(2011). Questionnaire was based on 5-point scale i.e. 1 stood for strongly disagree, 2 stood for disagree, 3 stood for neutral, 4 stood for agree and 5 stood for strongly agree. 


\subsubsection{Job Satisfaction}

For the measurement of job satisfaction five items were adopted from Hassall, S. L. (2009). Questionnaire was based on 5-point scale i.e. 1 stood for strongly disagree, 2 stood for disagree, 3 stood for neutral, 4 stood for agree and 5 stood for strongly agree.

\subsubsection{Organizational Commitment}

For the measurement of job autonomy eight items were adopted from Bashir, S.(2011). Questionnaire was based on 5-point scale i.e. 1 stood for strongly disagree, 2 stood for disagree, 3 stood for neutral, 4 stood for agree and 5 stood for strongly agree.

\subsubsection{Organizational Culture}

For the measurement of organizational culture fourteen items were adopted from Vadi, Allik \& Realo (2002). Questionnaire was based on 5-point scale i.e. 1 stood for strongly disagree, 2 stood for disagree, 3 stood for neutral, 4 stood for agree and 5 stood for strongly agree.

Table 2. Reliability statistics

\begin{tabular}{cc}
\hline Cronbach's Alpha & No of items \\
\hline .823 & 30 \\
\hline
\end{tabular}

Table 3. Detail of variables

\begin{tabular}{cccc}
\hline Variable & Adopted from & Number of items & Reliability \\
\hline JA & Bashir, S. (2011) & 3 & .721 \\
JS & Hassall, S. L. (2009) & 5 & .872 \\
OC (Organizational Commitment) & Bashir, S.(2011) & 8 & .817 \\
OC(Organizational Culture) & Vadi,M., Allik, J., \&Realo,A. (2002) & 14 & .773 \\
\hline
\end{tabular}

\section{Results}

From the demographics section it can be seen that 98 respondents were males and only 9 were females. It shows that there is male dominance in the fast food sector of Pakistan. Majority of the respondents were intermediate or less than intermediate. Only one respondent had a Master of Science (MS) degree. 40 respondents had bachelor's degree. It shows fast food sector of Pakistan is far behind in case of education.

\subsection{Hypothesis Testing}

With the help of literature review four hypotheses were developed and correlation as well as regression analysis were conducted with the help of SPSS in order to test those hypotheses. All the four hypotheses were accepted and it was found that job autonomy is significantly allied to job satisfaction and organizational commitment and organizational culture plays a moderating role in-between the relationshipof job autonomy, job satisfaction and organizational commitment.

Table 4. Correlation analysis

\begin{tabular}{lcccccc}
\hline \multicolumn{1}{c}{ Variable } & Mean & SD & JA & JS & $\begin{array}{c}\text { OC (Organizational } \\
\text { Commitment) }\end{array}$ & $\begin{array}{c}\text { OC(Organizational } \\
\text { Culture) }\end{array}$ \\
\hline JA & 3.33 & .593 & 1 & & \\
JS & 3.29 & .593 & $.332^{* *}$ & 1 & 1 & 1 \\
OC (Organizational & 3.07 & .838 & $.412^{* *}$ & $.352^{* *}$ & .114 & 1 \\
Commitment) & 3.19 & .707 & $.099^{* *}$ & .315 & & \\
$\begin{array}{l}\text { OC(Organizational } \\
\text { Culture) }\end{array}$ & & & & & & \\
\hline
\end{tabular}

Note: ${ }^{* *}$ Correlation is significant at the 0.01 level (2-tailed). 
Table 5. Regression analysis with job satisfaction as dependent variable

\begin{tabular}{llll}
\hline Variable & Beta & t value & Significance \\
\hline JA & .583 & 6.941 & 0.000 \\
\hline
\end{tabular}

$\mathrm{N}=107$, R square=.170, Adjusted R Square: .167, F: 48.176, Dependent Variable: Job Satisfaction.

Table 6. Regression analysis with organizational commitment as dependent variable

\begin{tabular}{llll}
\hline Variable & Beta & t value & Significance \\
\hline JA & .332 & 5.387 & 0.000 \\
\hline
\end{tabular}

$\mathrm{N}=107$, R square=.110, Adjusted R Square: .106, F: 29.024, Dependent Variable: Organizational Commitment.

Table 7. Moderated regression analysis with organizational commitment as dependent variable

\begin{tabular}{llll}
\hline & Beta & R square & Change in R square \\
\hline $\mathrm{JA}$ & .332 & .110 & .110 \\
$\mathrm{JA} * \mathrm{OC}$ & .433 & .188 & .078 \\
\hline
\end{tabular}

Table 8. Moderated regression analysis with job satisfaction as dependent variable

\begin{tabular}{llll}
\hline & Beta & R square & Change in R square \\
\hline $\mathrm{JA}$ & .583 & .170 & .170 \\
$\mathrm{JA} * \mathrm{OC}$ & .594 & .175 & .005 \\
\hline
\end{tabular}

\section{Discussion}

This study focused on four variables i.e. one independent variable, two dependent variables and a moderator in fast food restaurants of Rawalpindi and Islamabad, Pakistan. Increase in job autonomy was found to be significantly allied with an increase in job satisfaction and organizational commitment. Significant level ofsupport was also found for the moderating role of organizational culture in between the relationship of job autonomy, job satisfaction and organizational commitment. Job autonomy upsurges job satisfaction and organizational commitment because employees feel they are trusted by their organizations for tasks. This results in a higher level of intrinsic motivation and job satisfaction and more committed will be employees. If employees of an organization are committed then they will make serious efforts to learn, improve and grow.

In fast food sector of Pakistan employees are not very well educated but still they are contentedand happy with their jobs. They have freedom of work and they can make small decisions themselves. It's in the culture of fast food sector to give free hand to their employees so that their performance can be enhanced. Managers of fast food sector should give autonomy to employees after evaluating their performance as sometimes job autonomy can also result in job dissatisfaction. Need for autonomy in job varies with the personality of an individual. Some employees can't work and move without direction from a manager and don't feel comfortable with autonomy provided to them because they don't want to take responsibility of the outcomes of the tasks. Moreover if employees are not well trainedbut still they are provided autonomy then it will lead to poor performance.

\section{References}

Abdulla, M. H. A., \& Shaw, J. D. (1999). Personal Factors and Organizational Commitment: Main And Interactive Effects In The United Arab Emirates. Journal of Managerial Issues, 11(1), 77-93.

Addae, H. M., Parboteeah, K. P., \& Velinor, N. (2008). Role stressors and organizational commitment: public sector employment in St Lucia. International Journal of Manpower, 29(6), 567-582.http://dx.doi.org/10.1108/01437720810904220

Alhaji, I. A., \& Yusoff, W. F. (2012). Does motivational factor influence organizational commitment and effectiveness? A review of literature. Journal of Business Management and Economics, 3(1), 1-9. 
Al-Alawi, A. I., Al-Marzooqi, N. Y., \& Mohammed, Y. Y. (2007). Organizational culture and knowledge sharing: critical success factors. Journal of Knowledge Management, 11(2), 22-42. http://dx.doi.org/10.1108/13673270710738898

Angle, H. L., \& Perry, J. L. (1981). An Empirical Assessment of Organizational Commitment and Organizational Effectiveness. Administrative Science Quarterly, 26(1), 1-14. http://dx.doi.org/10.2307/2392596

Atak, M. (2011). A research on the relation between organizational commitment and learning organization. African Journal of Business Management, 5(14), 5612-5616.

Bashir, S. (2011). Organizational Cynicism, Development and Testing of an Integrated Model: A Study of Public Sector Employees in Pakistan. (Unpublished doctoral dissertation). Muhammad Ali Jinnah University, Karachi.

Black, J. S. (1988). Work role transitions: A study of American expatriate managers in japan. Journal of International Business Studies, 19(2), 277-294.http://dx.doi.org/10.1057/palgrave.jibs.8490383

Brey, P. (1999). Worker Autonomy and the Drama of Digital Networks in Organizations.Journal of Business Ethics, 22(1), 15-25. http://dx.doi.org/10.1023/A:1006199816737

Budd, J. M. (1996). The Organizational Culture of the Research University: Implications for LIS Education. Journal of Education for Library and Information Science, 37(2), 154-162. http://dx.doi.org/10.2307/40324270

Chang, C. C. L. (2011). Effects of social capital structure on organizational learning. African Journal of Business Management, 5(18), 7691-7701.

Chung, K. (1977). Motivational Theories and Practices. Columbus, OH: Grid Publishing.

Cole, M. S., \& Bruch, H. (2006). Organizational identity strength, identification, and commitment and their relationships to turnover intention: Does organizational hierarchy matter? Journal of Organizational Behaviour, 27, 585-605. http://dx.doi.org/10.1002/job.378

Dee, J., Henkin, A., \& Chen, J. (2000). Faculty autonomy: Perspectives from Taiwan. Higher Education, 40, 203-216. http://dx.doi.org/10.1023/A:1004009703603

Deshpande, R., \& Webster, F. E. (1989). Organizational culture and marketing: defining the research agenda. Journal of Marketing, 53(1), 3-15. http://dx.doi.org/10.2307/1251521

Dworkin, G. (1988). The theory and practice of autonomy. New York: Cambridge University Press. http://dx.doi.org/10.1017/CBO9780511625206

Ellickson, M. C., \& Logsdon, K. (2002). Determinants of job satisfaction of municipal government employees. Public Personnel Management, 31(3), 343-358.

Galunic, D. C., \& Anderson, E. (2000). From Security to Mobility: Generalized Investments in Human Capital and Agent Commitment. Organization Science, 11(1), 1-20.http://dx.doi.org/10.1287/orsc.11.1.1.12565

Gellatly, I. R., \& Irving, P. G. (2001). Personality, autonomy, and contextual performance of managers. Human Performance, 14, 229-243. http://dx.doi.org/10.1207/S15327043HUP1403_2

Gonzalez, T. F., \& Guillen, M. (2008). Organizational Commitment: A Proposal for a Wider Ethical Conceptualization of Normative Commitment. Journal of Business Ethics, 78(3), 401-414. http://dx.doi.org/10.1007/s10551-006-9333-9

Haas, L., \& Hwang, C. P. (2007). Gender and Organizational Culture. Gender \& Society, 21, 52-79. http://dx.doi.org/10.1177/0891243206295091

Hackman, J. R., \& Oldham, G. R. (1975). Development of the job diagnostic survey. Journal of Applied Psychology, 60, 159-170. http://dx.doi.org/10.1037/h0076546

Hackman, J. R., \& Oldham, G. R. (1976). Motivation through the design of work: Test of a theory. Organizational Behavior and Human Performance, 16, 250-279. http://dx.doi.org/10.1016/0030-5073(76)90016-7

Iqbal, A. (2010). An empirical assessment of demographic factors, organizational ranks. International Journal of Business and Management, 5(3), 16-27.

Jakonis, A. (2009). Culture of Japanese organization and basic determinants of institutional economy. Journal of 
Intercultural Management, 1(2), 90-104.

James, J. H. S. (2000). Reinforcing ethical decision making through organizational structure. Journal of Business Ethics, 28(1), 43-58. http://dx.doi.org/10.1023/A:1006261412704

Jamaludin, Z. (2011). Developing a "Tough to Copy" Competitive Advantage (OrganizationalCommitment) Through Perceived Organizational Justice. Journal of Global Management, 1(1), 57-70.

Johnson, J. P., Korsgaard, M. A., \& Sapienza, H. J. (2002). Perceived fairness, decision control, and commitment in international joint venture management teams. Strategic Management Journal, 23, 1141-1160. http://dx.doi.org/10.1002/smj.277

Judge, T. A., \& Watanabe, S. (1993). Another look at the job satisfaction-life satisfaction relationship. Journal of Applied Psychology, 78, 939-948. http://dx.doi.org/10.1037/0021-9010.78.6.939

Kassahun, T. (2005). Level of Organisational Commitment: Its Correlates and Predictors. Indian Journal of Industrial Relations, 14(1), 29-63.

Kehinde, O. A. (2011). Impact of Job Satisfaction on Absenteeism: A Correlative Study. European Journal of Humanities and Social Sciences, 1(1), 25-49.

Langfred, C. W., \& Moye, N. A. (2004). Effects of task autonomy on performance: An extended model considering motivational, informational and structural mechanisms. Journal of Applied Psychology, 89(6), 934-945. http://dx.doi.org/10.1037/0021-9010.89.6.934

Lease, S. (1998). Work attitude and outcomes. Journal of Vocational Behaviour, 53, 154-183. http://dx.doi.org/10.1006/jvbe.1998.1662

Leow, K. L., \& Khong, K. W. (2009). The Study of Mentoring and Leader-Member Exchange (LMX) on Organizational Commitment among Auditors in Malaysia. International Journal of Business and Information, 4(2), 161-198.

Leidner, D. E., \& Kayworth, T. (2006). A review of culture in information systems research: Toward atheory of information technology culture conflict. MIS Quarterly, 30(2), 357-399.

Lim, B. (1995). Examining the organizational culture and organizational performance link. Leadership \& Organization Development Journal, 16(5), 16-21. http://dx.doi.org/10.1108/01437739510088491

Linnenluecke, M. K., \& Griffiths, A. (2010). Corporate sustainability and organizational culture. Journal of World Business, 45, 357-366. http://dx.doi.org/10.1016/j.jwb.2009.08.006

Lo, M. C., Ramayah, T., \& Min, H. W. (2009). Leadership styles and organizational commitment: A test on Malaysia manufacturing industry. African Journal of Marketing Management, 1(6), 133-139.

Lok, P., \& Crawford, J. (2003). The effect of organizational culture and leadership styleon job satisfaction and organizational commitment. Journal of Management Development, 23(3/4), 321-338.

Marchese, M. C., \& Ryan, J. (2001). Capitalizing on the Benefits of Utilizing Part-Time Employees through Job

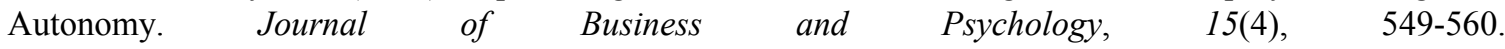
http://dx.doi.org/10.1023/A:1007814816178

McSweeney, B. (2002). Hofstede's model of national cultural differences and their consequences: A triumph of faith-a failure of analysis. Human Relations, 55(1), 89-118.

Mehmood, N., Irum, S., Ahmed, K., \& Sultana, A. (2012). A study of factors affecting job satisfaction (Evidence from Pakistan). Interdisciplinary Journal of Contemporary Research in Business, 4(6), 673-684.

Mehr, S. K., Emadi, S., Cheraghian, H., Roshani, F., \& Behzadi, F. (2012). Relationship between job satisfaction and organizational culture in staffs and experts of physical education offices of Mazandaran Province. European Journal of Experimental Biology, 2(4), 1029-1033.

Meyer, J. P., \& Allen, N. J. (1997). Commitment in the workplace: Theory, research, and application. Thousand Oaks, CA: Sage.

Mohamed, F., Taylor, G. S., \& Hassan, M. (2006). Affective Commitment and Intent to Quit: The Impact of Work and Non-work Related Issues. Journal of Managerial Issues, 18(4), 512-529.

Morgeson, F. P., Delaney-Klinger, K., \& Hemingway, M. A. (2005).The importance of job autonomy, cognitive ability, and job-related skill for predicting role breadth and job performance. Journal of Applied Psychology, 90, 399-406. http://dx.doi.org/10.1037/0021-9010.90.2.399 
Nicholson, N. (1984). A theory of work role transitions. Administrative Science Quarterly, 29, 172-191. http://dx.doi.org/10.2307/2393172

Ogbonna, E., \& Harris, L. C. (2000). Leadership style, organizational culture and performance: empirical evidence from UK companies. International Journal of Human Resource Management, 11(4), 766-788. http://dx.doi.org/10.1080/09585190050075114

Oshagbemi, T. (2003). Is length of service related to the level of job satisfaction? International Journal of Social Economics, 27(3), 213-226. http://dx.doi.org/10.1108/03068290010286546

Parker, S. K., Axtell, C. M., \& Turner, N. (2001). Designing a safer workplace: Importance of job autonomy, communication quality, and supportive supervisors. Journal of Occupational Health Psychology, 6, 211-228. http://dx.doi.org/10.1037/1076-8998.6.3.211

Pettigrew, A. M. (1979). On studying organizational cultures. Administrative Science Quarterly, 24, 570-81. http://dx.doi.org/10.2307/2392363

Podsakoff, P. M., MacKenzie, S. B., Paine, J. B., \& Bachrach, D. G. (2000). Organizational Citizenship Behaviors: A Critical Review of the Theoretical and Empirical Literature and Suggestions for Future Research. Journal of Management, 26(3), 513-563. http://dx.doi.org/10.1177/014920630002600307

Porter, J. K., Bacon, C. W., Robbins, J. D., \& Higman, H. C. (1975). A field indicator in plants associated with ergot-type toxicities in cattle. Journal of Agricultural and Food Chemistry, 23, 771-775. http://dx.doi.org/10.1021/jf60200a050

Robbins, S., \& Judge, T. (2007). Organizational Behavior. Upper Saddle River, NJ: Pearson Prentice Hall.

Rose, M. (2001). Disparate Measurers in the Workplace. Quantifying Overall Job Satisfaction: New Evidence. Colchester: Paper Presented at the 2001 British Household Panel Survey Research Conference.

Saks, A. M. (2006). Antecedents and consequences of employee engagement. Journal of Managerial Psychology, 21(7), 600-619. http://dx.doi.org/10.1108/02683940610690169

Saragih, S. (2011). The Effects of Job Autonomy on Work Outcomes: Self Efficacy as an Intervening Variable. International Research Journal of Business Studies, 4(3), 203-215.

Sarboland, K. (2012). Assessment of the Relationship between Emotional Intelligence and Organizational Commitment of Employees: A Case Study of Tax Affairs Offices, Iran. Journal of Basic and Applied Scientific Research, 2(5), 5164-5168.

Schwalbe, M. L. (1985). Autonomy in Work and Self-Esteem. The Sociological Quarterly, 24(6), 519-535. http://dx.doi.org/10.1111/j.1533-8525.1985.tb00242.x

Sinclair, R. R., Leo, C. M., \& Wright, C. (2005). Benefit system effects on employees'benefit knowledge, use and organizational commitment. Journal of Business and Psychology, 20(1), 3-29. http://dx.doi.org/10.1007/s10869-005-6981-1

Smith, E. S., Kot, G. E., \& Leat, M. (2003). Differentiating work autonomy facets in a non-Western context.Journal of Organizational Behavior, 24(6), 709-731. http://dx.doi.org/10.1002/job.200

Stevens, J. M., Beyer, J., \& Trice, H. M. (1978). Assessing personal, role and organizational predicto.

Tosi, H. L., \& Greckhamer, T. (2004). Culture and CEO Compensation.Organization Science, 15(6), 657-670. http://dx.doi.org/10.1287/orsc.1040.0099

Van Muijen, J. J., Koopman, P., De Witte, K., De Cock, G., Susanj, Z., Lemonine, C., \& Turnipseed, D. (1999). Organizational culture: The focus questionnaire. European Journal of Work and Organizational Psychology, 8(4), 555-568. http://dx.doi.org/10.1080/135943299398168

Weiss, H. M. (2002). Deconstructing job satisfaction: Separating evaluations, beliefs and affective experiences. Human Resource Management Review, 12, 173-194.http://dx.doi.org/10.1016/S1053-4822(02)00045-1

Willcoxson, L., \& Millett, B. (2000). The Management of Organizational Culture. Australian Journal of Management \& Organizational Behaviour, 3(2), 91-99.

\section{Copyrights}

Copyright for this article is retained by the author(s), with first publication rights granted to the journal.

This is an open-access article distributed under the terms and conditions of the Creative Commons Attribution license (http://creativecommons.org/licenses/by/3.0/). 